\title{
Determining Some Structural Characteristics and Mechanization Potential of Dairy Cattle Farms in Karacabey District of Bursa Province
}

\author{
Hilmi TUTAR ${ }^{1, *}$, Hakan Okyay MENGEŞ², \\ ${ }^{1}$ Sezer Agriculture and Milking Technologies, Bursa, Turkey \\ ${ }^{2}$ Selçuk University, Faculty of Agriculture, Department of Agricultural Machinery Technologies and Engineering,
} Konya, Turkey

\begin{tabular}{l}
\hline ARTICLE INFO \\
\hline Article history: \\
Received date: 19.07 .2019 \\
Accepted date: 31.01 .2020 \\
\hline Edited by: \\
Osman ÖZBEK; Selçuk University, \\
Turkey \\
Reviewed by: \\
Mehmet Hakan SONMETE; Selçuk \\
University, Turkey \\
Kazım ÇARMAN; Selçuk University, \\
Turkey \\
\hline Keywords: \\
Livestock \\
Barn \\
Milk Yield \\
Dairy Cattle Farms \\
\hline
\end{tabular}

\section{Introduction}

The Agricultural sector has increased its importance in improvement and industrialization process of developed and developing countries day by day. Even for developed countries, that are more focused on the industry and services., agriculture is still very important in economic and social terms (Demir and Sancar., 2012). The agricultural sector plays a very important role in the economy of the country, it does not only supply the population with food but also contributes with raw material for industrial sector, creates demand for industrial product, helps the national income as well as foreign currency for the country in terms of exportation (Tunç., 2018).

Agricultural Production is the activity of producing, storing and processing animal goods and vegetables under proper circumstances as well as the marketing

\footnotetext{
* Corresponding author email: hlmttr16@gmail.com * This study is summarized from Hilmi TUTAR's Master's thesis.
}

and permanent improvement of those mentioned before. (Doğan et al. 2015; Güzel 2016).

Husbandry sector supports important economical activities like supplying raw materials for several production lines, added value, increasing the income of the logistic sector and retailing, helping rural development, besides its contributions to the nutrition of the nationals. (Anonymous 2019).

About $90 \%$ of the production in the dairy sector, which is one of the most important components of the food sector, is obtained from milk cows, in Turkey, as is the case with worldwide. (Akman et al., 2010, Güzel 2016).

Dairy cattle production is an important branch of the livestock sector in our country and contributes to development of the country in various ways. Considering the producers, a big part of the population, which living in rural areas, in Turkey is to live off dairy cattle. Dairy cattle farming is managed as both in large-scale commercial enterprises and in several dairy cows as family businesses, especially in areas close to the provinces, that with large populations. Livestock activities require intensive labor force because of that, the large 
scale enterprises make significant contributions to employment in their provinces. Family businesses, which are more then other enterprises in number, contribute to the on site development of agrarian populations in every region. (Boz, 2013).

A healthy database is needed for forward-looking rational policies in the livestock sector. (Cenan, Gürcan 2011). In Turkey, there are many studies, aimed at determining the structural status of cattle raising enterprises in different provinces. Repetition of theses type of studies more commonly and at regular, is important in order to update the data in the sector, determine the current situation, keep track of changes over the years and determine the problems of the sector and produce solutions for these problems and finally to make rational planning for the future (Şeker et al., 2012; Güzel, 2016).

Some of the problems of the sector affect the entire sector on the country basis and others may differ from region to area or province. Therefore, working on the local level and searching the issue in depth are important, in order to develop consistent solution proposals. (Boz, 2013).

In this study, it is aimed to that, determine and evaluate the some structural and mechanization potential characteristics of dairy cattle farms in Karacabey District of Bursa province and to shed light on the regional policies to be implemented.

\section{Material And Method}

\subsection{Material}

The main material of this study, which examined some structural characteristics and mechanization potential of dairy cattle breeding enterprises in Karacabey district of Bursa province, where dairy cattle farms are concentrated, is the data obtained from one-to-one questionnaires conducted with owners or authorized persons in January-March 2019 period.

\subsection{Method}

\subsubsection{Detecting the enterprises will be searched on and preparing survey form}

Stratified random sampling method was used in the selection of the enterprises to be surveyed and the sample volume was calculated according to the following formula (Yamane, 2001).

$$
\mathrm{n}=\frac{\mathrm{N} \cdot \Sigma_{\mathrm{h}} \mathrm{S}^{2} \mathrm{~h}}{\mathrm{~N}^{2} \mathrm{D}^{2}+\mathrm{N}_{\mathrm{h}} \mathrm{S}^{2} \mathrm{~h}}
$$

In formula;

$\mathrm{n}$ : Sample volume,

$\mathrm{N}$ : Enterprise quantity in population

$\mathrm{Nh}$ : Enterprise quantity in "h" stratify
Sh2: Variance of "h" stratify

D2: Permissible fault amount from population average (D2 = (e/t)2),

e: Permissible fault lot from population average,

$\mathrm{t}$ : The value is,on distribution table, detected according to fault rate.

The number of sample farms, to be surveyed, was determined, by stratified random sampling method and considering the number of dairy cows in the farms, as 59 pcs with $1 \%$ error margin and $99 \%$ confidence limit.

The enterprises that make up the population are divided into 4 layers $(1-3,4-11,12-35,36+$ of the 4 size group) by taking into consideration the distribution of cows. The enterprises in the sample were distributed to the layers by using modulating distribution method $\mathrm{nh}$ $=(\mathrm{Nh} / \mathrm{N}) \mathrm{n}$. By this way, the surveys were conducted with the enterprises from the first layer 4pcs., the second layer 17 pcs., the third layer 18 pcs., the fourth layer 20 pcs., so the enterprises to be sampled, determined randomly from each layer. Besides, substitute enterprises were determined, as $10 \%$ of the sample volume, in cases that the responsibles of sample enterprises, can't be found at places (Güzel and Aybek 2017).

You can see at following table, the number of enterprises and the number of milking animals, for each group, in the enterprises, that divided into four layers

Table 1

Enterprise and Animal Quantity in Groups

\begin{tabular}{ccc} 
Enterprises Groups & Animal Qty. & Enterprises Qty \\
\hline 1. Group & $1-3$ & 4 \\
2. Group & $4-11$ & 17 \\
3. Group & $12-35$ & 18 \\
4. Group & $36+$ & 20 \\
Total & & 59 \\
\hline
\end{tabular}

In 59 questionnaires, conducted in Karacabey district, comprises the information about the characteristics of proprietor and employees (experience, education, training, etc.), general and structural characteristics of enterprises (land size, area of activity, animal species and numbers, animal milk yields, Shelter type and characteristics, time consumption of daily work on animals, forage crops grown and fed in the Enterprise, etc.), mechanization characteristics of the enterprises (machine type, number and characteristics, etc.), provision of machinery conditions and their expectations. The questionnaire consists of closed and open-ended questions.

\section{Results and Discussion}

The work experiences of the operators, in 59 dairy cattle enterprises, that are the subject of our research are divided according to the groups determined by the number of animals, in Table 2. Among the farms with 1-3 animal, the average period of husbandry is 42.5 years according to groups of operators experience as to this study. This value has been determined respectively as $26.5,27.7$ and 25.5 years for enterprises with 4-11, 
12-35 and lastly $36+$ animals. In general, average of the experience of 59 business owners was calculated as 27.5 years (Table 2). Özyürek et al., (2014), The study, conducted in the District of Erzincan province, reported that the average time of the experience of operators in cattle farming is 22 years.

Table 2

Experience of Enterprise Owners

\begin{tabular}{lcccc}
\hline $\begin{array}{l}\text { Experience of } \\
\text { Enterprise }\end{array}$ & \multicolumn{4}{c}{ Enterprise Groups } \\
\cline { 2 - 5 } $\begin{array}{l}\text { Owners } \\
\text { ani- } \\
\text { mal }\end{array}$ & $\begin{array}{c}4-11 \\
\text { ani- } \\
\text { mal }\end{array}$ & $\begin{array}{c}12-35 \\
\text { ani- } \\
\text { mal }\end{array}$ & $\begin{array}{c}36+ \\
\text { ani- } \\
\text { mal }\end{array}$ \\
\hline $\begin{array}{l}\text { Cattle Breeding } \\
\text { Duration (Ave- } \\
\text { rage year) }\end{array}$ & 42.5 & 26.5 & 27.7 & 25.5 \\
& & & & \\
\end{tabular}

The education level of producers in Karacabey district is given in Table 3. When the educational level of business owners is examined in, it is observed that there are no uneducated business owners. When the education level of the operators is examined, emergent

Table 3

Education Level of Enterprises Owner results are follows; in 1-3 groups; 3 of them primary schools graduate $(75 \%), 1$ of them secondary school graduate $(25 \%)$, in $4-11$ group; 17 of them primary schools graduate (100\%), in 12-35 group; 11 of them primary school graduate $(61.1 \%), 5$ of them secondary school graduate $(27.7 \%), 2$ of them high school graduate $(11.2 \%)$, among $36+$ groups; 13 of them primary school graduate $(65 \%), 3$ of them secondary school graduate $(15 \%), 2$ of them university graduate $(10 \%)$ and 2 of them postgraduate $(10 \%)$. As to the general average, $74.5 \%$ of enterprise owners elementary school graduate, $15.6 \%$ of them secondary school graduate, $3.3 \%$ of them high school graduate, $3.3 \%$ of them university graduate, and $3.3 \%$ of them postgraduate. (Table 3). (Gençoğlan, 2017), According to the study, conducted in Kahramanmaraş province, enterprise owners educational levels are follows; $46.4 \%$ of them primary school graduate, $21.5 \%$ of them high school graduate and $32.1 \%$ of them university graduate. (Avsever, 2016), Moreover the study, conducted in Ereğli District of Konya province, determined that; $74.83 \%$ of enterprise owners graduated from primary and secondary school.

\begin{tabular}{lcccccc}
\hline \multirow{2}{*}{ Groups } & \multicolumn{5}{c}{ Education Level Of Operator } \\
\cline { 2 - 6 } & Primary school & Secondary & High School & University & Postgradu- & Total \\
\hline $1-3$ animal & $3(75 \%)$ & $1(25 \%)$ & - & - & - & 4 \\
$4-11$ animal & $17(100 \%)$ & - & - & - & - & 17 \\
$12-35$ animal & $11(61.1 \%)$ & $5(27.7 \%)$ & $2(11.2 \%)$ & - & - & 18 \\
$36+$ animal & $13(65 \%)$ & $3(15 \%)$ & - & $2(10 \%)$ & $2(10 \%)$ & 20 \\
General & $44(74.5 \%)$ & $9(15.6 \%)$ & $2(3.3 \%)$ & $2(3.3 \%)$ & $2(3.3 \%)$ & 59 \\
\hline \multicolumn{7}{c}{$\chi^{2}=19.206 ; \mathrm{SD}=12 ; \mathrm{p}=0.084$} \\
\hline
\end{tabular}

Table 4 shows the land sizes of the enterprise groups. Considering the land sizes; among the groups with 1-3,4-11,12-35,36 + animals, total dry land sizes are $78,291,455,799$ respectively. And total sizes of irrigated land are 74, 464, 1701, 4223 respectively. (Güzel, and Aybek, 2017) In the study, done in Kahra-

Table 4

Land Sizes at Enterprises

\begin{tabular}{lccccc}
\hline Sizes of Land & \multicolumn{5}{c}{ Enterprise Groups } \\
\cline { 2 - 6 } Belong to Enter- & $1-3$ animal & $4-11$ animal & $12-35$ animal & $36+$ animal & Total \\
\hline Dry Land (da) & $78(51.3 \%)$ & $291(38 \%)$ & $455(21.1 \%)$ & $799(15.9 \%)$ & $1623(20 \%)$ \\
Irrigated Land (da) & $74(49.7 \%)$ & $464(62 \%)$ & $1701(78.9 \%)$ & $4223(84.1 \%)$ & $6462(80 \%)$ \\
Total (da) & $152(100 \%)$ & $755(100 \%)$ & $2156(100 \%)$ & $5022(100 \%)$ & $8085(100 \%)$ \\
\hline \multicolumn{7}{c}{$\chi^{2}=131.840 ; \mathrm{SD}=102 ; \mathrm{p}=0.025$} \\
\end{tabular}

$86.4 \%$ of dairy cattle farms are active in agriculture additively, while $13.6 \%$ are only engaged in dairy cattle. (Table 5). As to the results of (Özyürek et al., 2014), found in Çayırlı District of Erzincan province; manmaras province; determined average land sizes are, irrigated ones 8.2 hectares, dry ones 7.3 hectares and this research detected that, minimum irrigated land size is 1 hectare, maximum 100 hectares, and minimum dry land size is 1 hectare, maximum 30 hectares. 
Table 5

Enterprises that are engaged in Other Activities

\begin{tabular}{lccccc}
\hline \multirow{2}{*}{$\begin{array}{l}\text { Other activity area of } \\
\text { enterprise }\end{array}$} & \multicolumn{5}{c}{ Enterprise Groups } \\
\cline { 2 - 6 } Available & $1-3$ animal & $4-11$ animal & $12-35$ animal & $36+$ animal & Total \\
Not & $4(100 \%)$ & $15(88.2 \%)$ & $17(94.4 \%)$ & $15(75 \%)$ & $51(86.4 \%)$ \\
\hline
\end{tabular}

The distribution of 51 enterprises, that are interested in other branches of agriculture, with dairy cattle breeding, and their products are given in Table 6. As it can be seen from the table, corn $(74.5 \%)$ is produced by 38 enterprises. The group, which has the most corn production $(88.8 \%)$, is the $12-35$ group, with 16 quantity. Barley is produced by 29 of the enterprises $(56.8 \%)$. The highest barley production $(66.6 \%)$ is realized in 12 enterprises, which are at $12-35$ group. $11.8 \%$ of enterprises in total, produce vetch. In each 1-3,4-11,36 +groups, 2 producer grows vetch. Vetch is not produced in 12-35 group. There are no rye producers among the enterprises. Clover production is realized by 10 of the enterprises $(19.6 \%)$. The highest clover production $(23.5 \%)$ was detected at 4-11 group (Table 6)

Table 6

Products, are grown at Enterprises

\begin{tabular}{lccccc}
\hline \multirow{2}{*}{ Agricultural Products } & \multicolumn{4}{c}{ Enterprise Groups } & \multirow{2}{*}{ Total } \\
\cline { 2 - 5 } & $1-3$ animal & $4-11$ animal & $12-35$ animal & $36+$ animal & \\
\hline Maize & $4(100 \%)$ & $8(47 \%)$ & $16(88.8 \%)$ & $10(50 \%)$ & $38(74.5 \%)$ \\
Barley & $4(100 \%)$ & $6(35.2 \%)$ & $12(66.6 \%)$ & $7(35 \%)$ & $29(56.8 \%)$ \\
Vetch & $2(50 \%)$ & $2(11.7 \%)$ & - & $2(10 \%)$ & $6(11.8 \%)$ \\
Clover & $3(75 \%)$ & $4(23.5 \%)$ & $1(5.5 \%)$ & $2(10 \%)$ & $10(19.6 \%)$ \\
\hline
\end{tabular}

The data of the dairy cows, which are the basis for the formation of the research groups and farm numbers, are evaluated as follows. The total quantity of dairy cows, in 1-3 group, is 8 . In this group, dairy cow quantities are as follows; Holstein and Holstein hybrid is (50\%) 4 and (50\%) Simmental and Simmental Hybrid is also 4. In 4-11 group, dairy cow quantities are; Holstein and Holstein hybrid is $111(85.38 \%)$, Simmental and Simmental hybrid is $10(7.69 \%)$, Montofon is 9 $(6.93 \%)$. The breed distribution of 12-35 Group, which has 396 cows in total, is, Holstein and Holstein hybrid is $361(91.16 \%)$ Simmental and Simmental hybrids is $35(8.84 \%)$. Lastly, in $36+$ group, the total quantity is detected as 1111, and distribution of them is; 891 (80.20\%) Holstein and Holstein hybrid, (19.80\%) 220 Simmental and Simmental hybrid

Table7

Animal Specifications

\begin{tabular}{ccccccc}
\hline \multirow{2}{*}{\multicolumn{2}{c}{ Animal Specifications }} & \multicolumn{4}{c}{ Enterprise Groups } \\
\cline { 3 - 7 } & \multirow{3}{*}{ Cow } & & $1-3$ animal & $4-11$ animal & $12-35$ animal & $36+$ animal \\
\cline { 2 - 7 } & \multirow{3}{*}{ Quantity } & & 8 & 130 & 396 & 1111 \\
& \multirow{3}{*}{ Race (\%) } & Holstein and Hybrid & $75 \%$ & $85.3 \%$ & $91.1 \%$ & $80.2 \%$ \\
\cline { 3 - 7 } & & Simmental and Hybrid & $25 \%$ & $7.8 \%$ & $8.9 \%$ & $19.8 \%$ \\
\cline { 3 - 7 } & & Montofon & - & $6.9 \%$ & - & - \\
\hline
\end{tabular}

The barn types, used in the 59 enterprises, were found to that, among 1-3 group all of them are closed $(100 \%)$, in $4-11$ group $(5.9 \%)$ one of them is half-open, (94.1\%) 16pcs are closed, in 12-35 group, (44.4\%) 8 pcs are half-open, (55.6\%) 10 pcs are closed, and in $36+$ group $(95 \%) 19$ barns are half-open, and $1(5 \%)$ of
Among the four different enterprise groups, the Holstein and its hybrid are the most common breed and covering $86.4 \%$ of the total number. The Simmental and its hybrid are the most common breed after the Holstein and its hybrid, with $11.9 \%$ rate. Among enterprises, the least common dairy cow breed is the Montofon, with $1.7 \%$ rate. The study conducted by (Öztürk, 2009) in Mardin province, reported that among the current breeds Holstein (44.3\%) was the most common breed and second one is Simmental $(20.13 \%)$, on the other side the ranges of domestic breed and the brunet breed are $(38.58 \%)$, (4.97\%) respectively. This situation is in parallel with the results obtained. On the other hand (Özyürek et al., 2014) presented that, in the Erzincan region with $45.4 \%$ rate Brown and with $47.8 \%$ rate Yellow breed are dominant culture breed, while Black Holstein breed preferred less. 
According to this; the study conducted in Kars by (Tilki et al., 2013), $79.1 \%$ of enterprises, the study conducted, in Kayseri by (Uğurlu, and Şahin, 2010), $75.0 \%$ of enterprises, the study is conducted in Ağr1, by (Bakan, 2014) $97.2 \%$ of them are from closed; in case the study conducted by (Yener et al., 2013) shows that, in South East Anatolia Region, $17.5 \%$ of barns are closed and $8.5 \%$ of barns are semi-open.

Table 8

Barn Types

\begin{tabular}{lcccc}
\hline Barn & \multicolumn{4}{c}{ Enterprise Groups } \\
\cline { 2 - 5 } Types & $\begin{array}{c}1-3 \\
\text { animal }\end{array}$ & $\begin{array}{c}4-11 \\
\text { animal }\end{array}$ & $\begin{array}{c}12-35 \\
\text { animal }\end{array}$ & $\begin{array}{c}36+ \\
\text { animal }\end{array}$ \\
\hline $\begin{array}{l}\text { Closed } \\
\text { System }\end{array}$ & $100 \%$ & $94.1 \%$ & $55.6 \%$ & $5 \%$ \\
$\begin{array}{l}\text { Semi-open } \\
\text { Sytems }\end{array}$ & $-5.9 \%$ & $44.4 \%$ & $95 \%$ \\
\hline & $\chi^{2}=33.592 ; \mathrm{SD}=3 ; \mathrm{p}=0.000$ & \\
\hline
\end{tabular}

The floor material used in the barns are detected that; is in 1-3 group; (75\%) 3 barns are concrete, (25\%) 1 barn is soil, in 4-11 group; 17 barns (100\%) are concrete, in 12-35groupp, 18 barns $(100 \%)$ are concrete and in $36+$ groups 20 barsn are $(100 \%)$ concrete.

As the size of the barns increasing, the use of concrete as a base material becomes inevitable This can be interpreted as a necessity considering requirements such as cleaning, animal control and animal traffic. Table 9 shows the base material information of the enterprise groups.

(Mundan et al., 2018), in their study conducted in Şanlıurfa province, it was reported that $85.2 \%$ of operators preferred concrete structure and $14.8 \%$ preferred compressed soil as shelter ground in dairy cattle enterprises. On the other hand, (Şeker et al., 2012) determined that breeders generally used concrete (59\%), then Stone (20.5\%), soil (16.4\%) and wood (4.1\%) for base of the barn.

Table 9

Barn Floor Material

\begin{tabular}{lcccc}
\hline \multirow{2}{*}{ Barn Floor } & \multicolumn{5}{c}{ Enterprise Groups } \\
\cline { 2 - 5 } Material & $\begin{array}{c}1-3 \\
\text { animal }\end{array}$ & $\begin{array}{c}4-11 \\
\text { ani- } \\
\text { mal }\end{array}$ & $\begin{array}{c}12-35 \\
\text { ani- } \\
\text { mal }\end{array}$ & $\begin{array}{c}36+ \\
\text { ani- } \\
\text { mal }\end{array}$ \\
\hline Concrete & $75 \%$ & $100 \%$ & $100 \%$ & $100 \%$ \\
Soil & $25 \%$ & - & - & - \\
\hline \multicolumn{4}{c}{$\chi 2=33.592 ; \mathrm{SD}=3 ; \mathrm{p}=0.576$} \\
\hline
\end{tabular}

Barn size averages, which differ by business groups, have been discussed. In the light of the data, among the enterprise groups, the highest average barn size is $936 \mathrm{~m} 2$ in $36+$ group. When looking at the groups; 12- 35 group values, the average barn size is 356 $\mathrm{m} 2$, in 4-11 group the it is $104 \mathrm{~m} 2$, and among 1-3 group it is $42 \mathrm{~m} 2$. (Table 9).

In Table 10, the status of the barns ventilation chimneys, which were important in the enterprises, were given. The situations of chimney, according to groups as follow; in 1-3 group, $2(50 \%)$ enterprises have, two of them $(50 \%)$ do not, in 4-11 group, 8 enterprises have $(47.1 \%), 9$ of the $(52.9 \%)$ do not, in 12 35 group; 10 enterprises $(55.6 \%)$ have and 8 of them $(44.4 \%)$ do not and in 36+ group $5(25 \%)$ enterprises have and 15 of them $(75 \%)$ do not. In addition, when we looked at enterprises in general, $42.4 \%$ of the enterprises have ventilation chimneys and $57.6 \%$ of them do not.

(Özyürek et al. 2014), the study examined in the region, $86.3 \%$ of the barns have ventilation chimneys, $13.7 \%$ of them do not have. Also in the study conducted by (Öztürk, 2009) in Mardin province $5.17 \%$ of of existing barns have ventilation chimneys, while $44.83 \%$ of them do not.

Table 10

Barn Size and Ventilation

\begin{tabular}{lccccc}
\hline \multirow{2}{*}{ Changeable Factors } & \multicolumn{4}{c}{ Enterprise Groups } \\
\cline { 2 - 5 } & $\begin{array}{c}1-3 \\
\text { animal }\end{array}$ & $\begin{array}{c}4-11 \\
\text { animal }\end{array}$ & $\begin{array}{c}12-35 \\
\text { animal }\end{array}$ & $\begin{array}{c}36+ \\
\text { animal }\end{array}$ \\
\hline Barn Size $\left(\mathrm{m}^{2}\right)$ & 42 & 104 & 356 & 936 \\
\hline \begin{tabular}{l} 
Barn $\begin{array}{l}\text { Ventila- } \\
\text { tion Pipe }\end{array}$ \\
\cline { 2 - 5 }
\end{tabular} & $\begin{array}{l}\text { Avai- } \\
\text { lable }\end{array}$ & $50 \%$ & $47.1 \%$ & $55.6 \%$ & $25 \%$ \\
\hline \multicolumn{5}{c}{$\chi^{2}=138.738 ; \mathrm{SD}=135 ; \mathrm{p}=0.395$} \\
\hline
\end{tabular}

Calf partitions form in enterprises, are seen as; in 13 group $2(50 \%)$ of them has separate partition at same barn, 1 of them (25\%) has no separate partition and 1 of them $(25 \%)$ separate partition at different barns. 4-11 group has the most diversity in this subject. Accordingly, calves are raised, in separate partitions in the same barn at 8 enterprises $(47.1 \%)$, at 6 enterprises $(35.3 \%)$, at same barn with mother, at 1 enterprise $(5.9 \%)$ at individual calf cage and at 2 enterprises $(11.8 \%)$ in separate partition at different barns. In 1235 group, calves are grown in separate partition in the same barn in 7 of the businesses $(38.9 \%)$, in 5 of them $(27.8 \%)$ individual calf cage is used and in 6 enterprises $(33.3 \%)$ use separate partition at different barns. In 36 +group, calves are grown in separate partition in the same barn in 5 of the enterprises $(25 \%)$, in individual calf cages in 10 enterprises (55\%), and in separate partitions in different barns in 3 enterprises (20\%). The rate of usage separate partitions for calves, among businesses, is $84.7 \%$ (Table 11).

Özyürek et al., (2014) in their study, 59\% of businesses found calves to be free in a separate partitions, while $41 \%$ said they grown them in a separate partitions, (Öztürk, 2009) and in the study, 93.9\% of the businesses observed that calf partitions were located in the barn. 
Table 11

Calf Partition Forms

\begin{tabular}{lcccc}
\hline & \multicolumn{4}{c}{ Enterprise Groups } \\
\cline { 2 - 5 } $\begin{array}{l}\text { Calf Partition } \\
\text { Forms }\end{array}$ & $\begin{array}{c}1-3 \\
\text { animal }\end{array}$ & $\begin{array}{c}4-11 \\
\text { animal }\end{array}$ & $\begin{array}{c}12-35 \\
\text { animal }\end{array}$ & $\begin{array}{c}36+ \\
\text { animal }\end{array}$ \\
\hline $\begin{array}{l}\text { Separate Partition } \\
\text { at the same barn }\end{array}$ & $50 \%$ & $47.1 \%$ & $38.9 \%$ & $25 \%$ \\
\cline { 2 - 5 } $\begin{array}{l}\text { At the same barn } \\
\text { with mother }\end{array}$ & $25 \%$ & $35.3 \%$ & - & - \\
\cline { 2 - 5 } $\begin{array}{l}\text { Individual Calf } \\
\text { Cage }\end{array}$ & - & $5.9 \%$ & $27.8 \%$ & $55 \%$ \\
\cline { 2 - 5 } $\begin{array}{l}\text { Separate Partiti- } \\
\text { ons at different }\end{array}$ & $25 \%$ & $11.7 \%$ & $33.3 \%$ & $20 \%$ \\
\hline \multicolumn{4}{c}{$\chi 2=25.318 ; \mathrm{SD}=9 ; \mathrm{p}=0.003$} \\
\hline
\end{tabular}

In 4 enterprises of 1-3 group (100\%), cows that give birth have no separate places. Among 4-11 group; 5 enterprises $(29.4 \%)$ have separate places for cows to give birth, in 12 businesses, it is not available. In 12-35 group, 10 enterprises $(55.6 \%)$ have separate places for the cow for birth, 8 enterprises $(44.4 \%)$ do not. The group with the highest number of separate places for cows to give birth, is the $36+$ Group. Accordingly, 16 enterprises $(80 \%)$ have separate places while 4 enterprises $(20 \%)$ do not (Table 12). In general, it is determined that, $52.5 \%$ of enterprises have separate places for cows to give birth. Here under, as the size of enterprises increases, it is observed that there are more individual places needed for animals. In similar studies have been conducted by; (Öztürk, 2009) and (Özyürek et al., 2014 ) it is detected that, respectively $45.5 \%$ and $6.6 \%$ of enterprises have separate places for cows to give birth. When studies examined it is seen that, similar results were found with (Öztürk, 2009), while results is seen to be different with (Özyürek et al., 2014).

Table 12

Separate Place for Birth

\begin{tabular}{lcccc}
\hline \multirow{4}{*}{$\begin{array}{l}\text { Separate Place } \\
\text { for Birth }\end{array}$} & $\begin{array}{c}1-3 \\
\text { ani- } \\
\text { mal }\end{array}$ & $\begin{array}{c}4-11 \\
\text { animal }\end{array}$ & $\begin{array}{c}12-35 \\
\text { animal }\end{array}$ & $\begin{array}{c}36+ \\
\text { ani- } \\
\text { mal }\end{array}$ \\
\hline Available & - & $29.4 \%$ & $55.6 \%$ & $80 \%$ \\
\cline { 2 - 5 } Not & $100 \%$ & $70.6 \%$ & $44.4 \%$ & $20 \%$ \\
\hline \multicolumn{4}{c}{$\chi^{2}=14.189 ; \mathrm{SD}=3 ; \mathrm{p}=0.003$} \\
\end{tabular}

In Table 13, the average milk yields of 59 business groups that are the subject of research, are observed. As can be seen from the examination of the table, average milk yields were determined as $16.2 \mathrm{~kg}$ in $1-3$ group, $17.3 \mathrm{~kg}$ in $4-11$ group, $18.8 \mathrm{~kg}$ in $12-35$ group and $20.1 \mathrm{~kg}$ in $36+$ group. In general, the results were found to be $18.1 \mathrm{~kg}$ day- 1 .
Şeker et al., (2012), reported that, the proportion of whom reported getting an average of $15 \mathrm{~kg}$ and more milk per day in the study was $3.2 \%$ and $78.4 \%$ of business reported having an average daily milk yield of 7 $\mathrm{kg}$ and less.

Elmaz et al., (2010), in the study of, Burdur province dairy cattle production and its characteristics, they reported that the average of the milk yield is 18.7

Table 13

Milk Yield

\begin{tabular}{lcccc}
\hline \multirow{2}{*}{ Milk Yield } & \multicolumn{4}{c}{ Enterprises Groups } \\
\cline { 2 - 5 } & $1-3$ & $4-11$ & $12-35$ & $36+$ \\
\hline $\begin{array}{l}\text { Average Milk Yield } \\
\text { (kg day-1) }\end{array}$ & 16.2 & 17.3 & 18.8 & 20.1 \\
\hline
\end{tabular}

Milking in enterprises in the region,1-3 group (100\%) with milking machine in the 3 businesses,4-11 group (88.2\%)with Mobile machine in 15 businesses, (11.8\%) 2 milking systems in 12-35 group(77.8\%), 14 Mobile machine(22.2\%), 4 milking systems and finally; in $36+\operatorname{group}(20 \%) 4$ enterprises mobile machine $(80 \%), 16$ operation milking systems was found be carried out.Looking at the overall to 59 businesses $(62.7 \%)$, the part of 37 , the milking process with Mobile machine $(37.3 \%)$, and the part of 22 was found to be carried out bu milking systems.(Table 14). In addition, it was found out that; the enterprises, which have big quantity animals, $(36+$ heads $)(80 \%)$ preferred milking systems.

Akar, (2015) stated in the study conducted in Muş plain that; $75 \%$ of the 73 farms have milking machines and 10 of these milking machines; are pipeline milking systems and 47 of them are mobile machines. (Öztürk, 2009), In the study carried out in Mardin province, $95.24 \%$ of the operators milked by hand and $4.76 \%$ by machine. (Demir, Sancar, 2012), Gümüşhane province Kelkit, Köse and Şiran districts of $37.3 \%$ of businesses by hand, $62.7 \%$ of mobile machine milking highlights. (Akbaș, et al., 2015), The results he encountered in his work in 39 provinces were that $93 \%$ of the visited businesses milked in the milking room while $7 \%$ milked in the barn.

When the types of milking systems used in the enterprises that are the subject research are evaluated; in 4-11 group enterprises 2 pipeline milking system $(11.8 \%)$, in 12-35 group 1 herringbone milking system (5.6\%), 3 pipeline milking system $(16.6 \%)$ and in $36+$ group; 7 herringbone milking system $(35 \%), 9$ pipeline milking system $(45 \%)$ is used (Table 15$)$.

Gençoğlan, (2017), in the study carried out in Kahramanmaraş province, $65.5 \%$ of the enterprises have a milking parlor, while $17.2 \%$ of the enterprises have a parallel milking system, $48.3 \%$ used a herringbone milking system. 
Table 14

Enterprises Milking Types

\begin{tabular}{|c|c|c|c|c|c|}
\hline \multirow{2}{*}{ Milking Type } & \multicolumn{4}{|c|}{ Enterprise Groups } & \multirow{2}{*}{ Total } \\
\hline & 1-3 animal & 4-11 animal & 12-35 animal & $36+$ animal & \\
\hline By Mobile Machine & $4(100 \%)$ & $15(88.2 \%)$ & $14(77.8 \%)$ & $4(20 \%)$ & $37(62.7 \%)$ \\
\hline By Milking System & - & $2(11.8 \%)$ & $4(22.2 \%)$ & $16(80 \%)$ & $22(37.3 \%)$ \\
\hline \multicolumn{6}{|c|}{$\chi 2=24.464 ; \mathrm{SD}=3 ; \mathrm{p}=0.000$} \\
\hline
\end{tabular}

Table 15

Milking Systems Types at Enterprises

\begin{tabular}{|c|c|c|c|c|c|}
\hline \multirow{2}{*}{ Milking System Types } & \multicolumn{4}{|c|}{ Enterprise Groups } & \multirow{2}{*}{ Total } \\
\hline & 1-3 animal & 4-11 animal & 12-35 animal & $36+$ animal & \\
\hline Herringbone Milking System & - & - & $1(5.60 \%)$ & $7(35 \%)$ & $8(36.3 \%)$ \\
\hline Pipeline Milking System & - & $2(11.8 \%)$ & $3(16.6 \%)$ & $9(45 \%)$ & $14(63.7 \%)$ \\
\hline General & - & $2(9.3 \%)$ & $4(18.3 \%)$ & $16(72.3 \%)$ & $22(100 \%)$ \\
\hline
\end{tabular}

\section{Conclusion and Recommendations}

It has been found that the work experience of the breeders in the enterprises decreases as the number of animals increases and this shows that the new generations started animal husbandry in high numbers. In parallel with this, it is determined that the education level is high in the enterprises with high number of animals. Regular training can be provided for small enterprises (1-3 heads, 4-11 heads) in order to benefit from this.

The big part of dairy cattle enterprises are involved in other agricultural activities with dairy cattle. Enterprises in different area of business will be beneficial to the business economy and will respond to various needs. To increase such activities and to encourage business owners, various facilities such as low-interest credit can be provided.

Among the enterprises engaged in agricultural activities, mainly forage corn is grown although barley, alfalfa, vetch.

According to the research data, the average land size of enterprises, with large numbers of animals, was seen to be greater than. This can be related to the economy and the need for forage crops in the farm compared to the number of animals.

According to the results of the study in Karacabey region, the dominant race, density was determined as Holstein, Simmental and Montofon respectively.

The barn types in the area are two varieties, closed and semi-open. Among these, it is seen that closed barns stand out and open barns are in enterprises with more animals. Barn type selection is very important for both

animal welfare and business owner workload. According to this, modern projects can be developed for business owners to minimize animal welfare and keep animal welfare at the highest level and business owners can be informed and encouraged in this regard.

Generally used in barns, the floor material is concrete. Concrete is preferred in livestock farms due to its strength and ease of cleaning.

Barn sizes vary from $42 \mathrm{~m}^{2}$ to $936 \mathrm{~m}^{2}$. Considering the cow and calf factors that will give birth in most 1-3 enterprises group, it is thought to be insufficient. Ventilation in enterprises is not sufficient. Generally, ventilation is provided by using fan or ridge suitable for barn structure, in large scale enterprises.

A separate place for cows to give birth is never found in small businesses, it is has seen in half of medium-sized businesses and close to all large-sized businesses. Calves have special importance in business economics. Based on this, hygiene and optimum conditions should be ensured for healthy calves and space must be reserved for cows to give birth in the farms.

Milk averages, which are the main source of income in enterprises, were seen as $16.25 \mathrm{~kg}$ day- 1 in small enterprises and $20.1 \mathrm{~kg}$ day-1 in large enterprises. Considering this in detail, it can be based on the differences between enterprises. They are; care, hygiene, animal welfare etc.

Statistically significance was determined between enterprise size and land size, barn type, calf partitions, delivery room status, milking system type.

The main aim of dairy cattle production enterprises is to obtain high quality, healthy, hygienic and high yield milk, but the study shows that many enterprises have deficiencies in this regard. In the scope of the study, no milking enterprises, which milk by hand were found, while many of the enterprises use mobile milking machines. It is seen that mobile machines are more primitive and simple than milking systems and milking systems are more developed in terms of hygiene. 
In the light of the data obtained, we consider that the study will be beneficial for the sector-related planning in the district.

\section{References}

Anonymous (2019). Kırmızı Et Stratejisi. Tarım ve Orman Bakanlığ1, Ankara. https://www.tarimorman.gov.tr/HAYGEM/Belgeler /Hayvanc\%C4\%B11\%C4\%B1k/K\%C4\%B1rm\%C4 \%B1z\%C4\%B1\%20Et\%20Stratejisi.pdf

Akar M (2015). Muş Ovasının Tarımsal Mekanizasyon Özellikleri ve 12 Hektar Büyüklüğünde Bir İşletme İçin En Uygun Bitki Deseninin Belirlenmesi, Atatürk Üniversitesi, Fen Bilimleri Enstitüsü, Yüksek Lisans Tezi, 112 sayfa, Erzurum

Akbaş T, Şimşek E, Çetin M (2015). Türkiye'de kırsal kalkınma yatırımlarının desteklenmesi programı çerçevesinde kurulan bazı süt sağım tesislerinin yapısal özellikleri. Adnan Menderes Üniversitesi Ziraat Fakültesi Dergisi, Sayfa 91-95

Akman N, Tuncel E, Tüzemen N, Kumlu S, Özder M, Ulutaş Z (2010). Türkiye Sığırcılık İşletmelerinin Yapısı ve Geleceğin Sığırcılık İşletmeleri. TMMOB Ziraat Mühendisleri Odası, Ziraat Mühendisliği VII. Teknik Kongresi, Bildiriler Kitabı 2, S651665.

Avsever F (2016). Konya İli Ereğli İlçesi Süt Sığırcılığı İşletmelerinin Yapısal Özellikleri, Selçuk Üniv Fen Bil Enst. Yüksek Lisans Tezi, 43 sayfa, Konya

Bakan Ö (2014). Ağrı İli Süt Sığırcılığı İşletmelerinin Yapısal Özellikleri. Atatürk Üniversitesi Fen. Bilimleri. Enstitüsü, Zootekni ABD, Yüksek Lisans Tezi, 92 s, Erzurum

Boz İ (2013). Doğu Akdeniz Bölgesi'nde süt sığırcılığ1 yapan işletmelerin yapısı, sorunları ve çözüm önerileri. KSÜ Doğa Bilimleri Dergisi, 16(1), 24-32.

Cenan N, Gürcan İS (2011). Türkiye çiftlik hayvan sayılarının ileriye yönelik projeksiyonu: ARIMA Modellemesi. Vet Hekim Der Derg 82(1): 35-42,

Demir N, Sancar C (2012). Gümüşhane İli ve Çevresinde Süt Sığırcılığı Yapan İşletmelerin Sosyal, Ekonomik ve Teknik Analizi. Alınteri Zirai Bilimler Dergisi, 23(2), 18-28.

Doğan Z, Arslan S, Berkman A (2015). Türkiye'de Tarım Sektörünün İktisadi Gelişimi ve Sorunları: Tarihsel Bir Bakış. Niğde Üniversitesi İktisadi ve İdari Bilimler Fakültesi Dergisi, 8(1), 29-41.

Elmaz Ö, Saatc1 M, Metin MÖ, Sipahi C (2010). Burdur İli Süt Sığırcılığı ve Özellikleri (Proje No 0038NAP-08), Mehmet Akif Ersoy Üniversitesi, Bilimsel Araştırma Projeleri Koordinatörlüğü
Gençoğlan S (2017). Kahramanmaraş İlinde Süt Sığırı İşletmelerinde Bulunan Merkezi Sağım Sistemlerinin Mevcut Durumunun ve Yapısal Özelliklerinin Belirlenmesi. Atatürk Üniversitesi Ziraat Fakültesi Dergisi, 48(2), 107-111.

Güzel M (2016). Kahramanmaraş İli Süt Sı̆̆ırcılığ1 İşletmelerinin Yapısal ve Mekanizasyon Özelliklerinin Belirlenmesi ve Değerlendirilmesi. Yüksek Lisans Tezi, Kahramanmaraş Sütçü İmam Üniversitesi, Fen Bilimleri Enstitüsü, Kahramanmaraş.

Güzel M, Aybek A (2017). Kahramanmaraş İli Süt Sı ğırcılığı İşletmelerinin Mekanizasyon Yapısı. Ksü Doğa Bilimleri Dergisi, 20(2), 148-159.

Mundan D, Atalar B, Meral BA, Yakışan MM (2018). Modern Süt Sı ğırı İşletmelerinin Yapısal Ve Teknik Özelliklerinin Belirlenmesi Üzerine Bir Araştırma. Atatürk Üniversitesi Veteriner Bilimleri Dergisi, 13(2), 201-210.

Özyürek S, Koçyiğit R, Tüzemen N (2014). Erzincan İlinde süt sığırcılığı yapan işletmelerin yapısal özellikleri: Çayırlı İlçesi örneği.

Öztürk NN (2009). Mardin ilindeki süt sığırcılığı işletmelerinin yapısal özellikleri Yüksek Lisans Tezi, Selçuk Üniversitesi Fen Bilimleri Enstitüsü). 74 sayfa.

Şeker İ, Tasalı H, Güler H (2012). Muş ilinde sı ğır yetiştiriciliği yapılan işletmelerin yapısal özellikleri. Fırat Üniversitesi Sağlık. Bilimleri Veterinerlik Dergisi, 26(1), 09-16.

Tilki M, Sarı M, Aydın E, Işık S, Aksoy AR (2013). Kars İli Sı̆̆ır İşletmelerinde Barınakların Mevcut Durumu ve Yetiştirici Talepleri: I. Mevcut Durum. Kafkas Üniversitesi Veteriner Fakültesi Dergisi, 19(1):109- 116.

Tunç H (2018). Tarımda Gıda Arzı ve Güvenliğinin EkonomiPolitiği.

http://www.havvatunc.com/2018/04/16/tarimsalgida-arzi-ve-guvenliginin-ekonomi-politigi/

Uğurlu N, Şahin S (2010). Kayseri İli Süt Sığırı Bar1naklarının Yapısal Özellikleri. Selçuk Tarım ve G1da Bilimleri Dergisi, 24(2): 23-26.

Yamane T (2001). Temel Örneklem Yöntemleri. Çevirenler: Alptekin Esin, Celal Aydın, M. Akif Bakır, Esen Gürbüzsel. Literatür Yayınları, Yayın No: 53, İstanbul, $509 \mathrm{~s}$.

Yener H, Atalar B, Mundan D (2013). Şanlıurfa İlindeki Sığırcılık İşletmelerinin Biyogüvenlik ve Hayvan Refahı Açısından Değerlendirilmesi. Harran Üniversitesi Veteriner Fakültesi Dergisi, 2(2), 87-93. 